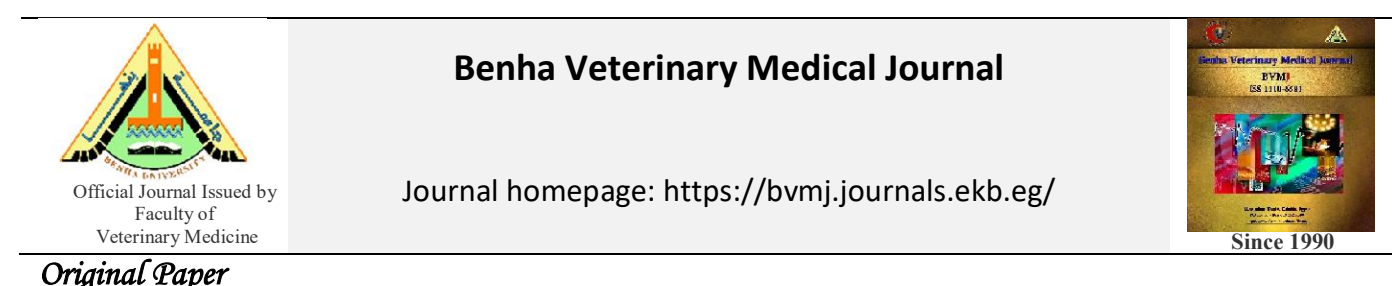

\title{
Control of some heavy metals contaminating fish products
}

Saad M. Saad ${ }^{1}$, Shimaa M. Nada ${ }^{2}$, Mahmoud F. Nada ${ }^{2}$.

${ }^{l}$ Food Hygiene and Control Department, Faculty of Veterinary Medicin, Benha University Egypt

${ }^{2}$ Animal Health research institute, Shebin El koom branch

\section{ARTICLE INFO}

\begin{tabular}{l}
\hline Keywords \\
Heavy metals \\
Fish products \\
Smoked herring \\
Received $13 / 03 / 2021$ \\
Accepted $24 / 03 / 2021$ \\
Available On-Line \\
01/07/2021
\end{tabular}

\begin{abstract}
One hundred random samples of fesiekh, sardine, smoked herring, and canned tuna (25 of each) obtained from different localities in Menoufia governorate, Egypt and estimated for their harmful residues including heavy metals (mercury, lead, cadmium and iron). Additionally, trials to control such serious residues by using biological techniques were applied. It was found that the average values of mercury in the investigated samples of fesiekh, sardine, smoked herring and canned tuna were $1.14 \pm 0.02,0.98 \pm 0.01,0.83 \pm$ 0.01 and $0.65 \pm 0.01 \mathrm{mg} / \mathrm{kg}$ respectively and in lead they were $0.54 \pm 0.01,0.42 \pm 0.01,0.29 \pm$ 0.01 and $0.23 \pm 0.01 \mathrm{mg} / \mathrm{kg}$, respectively. The cadmium residues average concentrations in the examined samples of fesiekh sardine, smoked herring and canned tuna were $0.33 \pm 0.01$, $0.21 \pm 0.01,0.16 \pm 0.01$ and $0.09 \pm 0.01 \mathrm{mg} / \mathrm{kg}$, respectively while, in iron they were $1.71 \pm$ $0.02,0.65 \pm 0.01,1.06 \pm 0.02$ and $0.93 \pm 0.01 \mathrm{mg} / \mathrm{kg}$, respectively. The effect of $L$. rhamnosus culture $(1 \times 107)$ on the levels of lead experimentally inoculated to sardine fillets $(30 \mathrm{mg} / \mathrm{Kg})$ was decreased to $13.8 \mathrm{mg} / \mathrm{kg}$ after 8 hours, $7.9 \mathrm{mg} / \mathrm{kg}$ after 12 hours and $6.5 \mathrm{mg} / \mathrm{kg}$ after 24 hours by a percentage of reduction $54 \%, 73.7 \%$ and $78.3 \%$ reduction, respectively.
\end{abstract}

\section{INTRODUCTION}

Fish products are commonly eaten in many places of the world because they contain high protein levels, low saturated fatty acids, phosphorus, calcium, iron, and trace elements like copper, as well as a good source of group B vitamins, all of which contribute to good health (Nkpaa et al., 2013).

Many chemical elements in seafood, however, can be harmful at high concentrations for human life in low concentrations. Other elements, such as lead $(\mathrm{Pb})$, cadmium $(\mathrm{Cd})$, and mercury $(\mathrm{Hg})$, are of no biological importance and are not toxic when ingested over time at low concentrations. Consequently, the presence of these elements in fish is seen by many clients as a health risk (Oehlenschläger, 2005).

Even at extremely low levels of the species, heavy metals such as cadmium, lead, copper and specifically mercury have been identified as dangerous environmental contaminants that can accumulate with serious risks for animal and human health (Bakhiet, 2015).

Methyl mercury successfully breached both the placental and blood-brain barriers, resulting in higher mercury concentrations in the foetus' brain than in the mother's. Furthermore, methyl mercury is primarily eliminated by bile and feces (WHO, 2004).

Lead contamination comes from a variety of sources, including heavy use in foundries, manufacturing operations, and use of paint pigments and glazes for ceramics (Storelli and Marcotrigiano ,2001). In Egypt the important sources of lead fish poisoning are industrial discharges (batteries factories, steel and iron factories, coal factories and canned food factories) and agriculture

*Corresponding author: mahmoudnadanada75@gmail.com discharges as super phosphate fertilizers (Daoud-Jehan et al. 1999).

Cadmium is commonly distributed in the atmosphere at relatively low concentrations. Large concentrations are found in hotspots associated with human activities, as well as agricultural lands where phosphate fertilizers and manure are spread in high concentrations (Scoullos et al., 2001).

Excessive lead intake leads to a loss of memory, mood swings, nerve and joint disorders and heart, skeletal and renal disease as well as excessive muscle intake (Environmental Working Group ,2010).

Heavy metals contamination is of major toxicity and has a variety of adverse effects on humans. carcinogenicity, mutagenicity, immunosuppression, teratogenicity, and emaciation are commonly associated toxicity with chronic exposure (Lehmann et al.,2011).

Heavy metals affect the organism in two ways; first is bioaccumulation and the second one is the disruption of normal cell processes that leading to toxicity (Vilizzi and Tarkan ,2018).

Several microbial genera are used as starter cultures for fermented meat products. Although the most used belong to the group of lactic acid bacteria and Gram-positive catalase-positive cocci $(\mathrm{GCC}+)$, mainly represented by Staphylococcus spp. and Kocuria spp. (Laranjo et al.,2017), other starter cultures belong Lactococcus spp., Leuconostoc spp., Enterococcocus spp. and Pediococcus spp. are also used (Franciosa et al.,2018).

Therefore, the present study was planned out to secure the following topics: 
- Determination of some heavy metal residues in the examined fish products (mercury, lead, cadmium, and iron)

- Investigation of the effect of L. rhamnosus culture (1x107) on the levels of lead experimentally inoculated to sardine fillets.

\section{MATERIAL AND METHODS}

\subsection{Determination of heavy metals}

2.1.1. Washing procedures (Lars, 2003)

Washing of equipment is a critical process to avoid contamination with the analyzed element .

Glass wares and vessels were thoroughly cleaned with deionized water and soaked in hot diluted HNO3 (10\%) for 24 hours and rinsed several times with deionized water and dried to ascertain that all the equipment were metal free . Further, the digestion vessels were immersed in water and soap for two hours then washed many times with water. They were rinsed once with distilled water, once with the mixture $(250 \mathrm{ml}$ de-ionized water, $200 \mathrm{ml}$ of concentrated $\mathrm{HCl}$ and $80 \mathrm{ml} \mathrm{H} 2 \mathrm{O} 2$ ) and once with $10 \% \mathrm{HNO}$.

2.1.2. Digestion technique (Staniskiene et al., 2006)

One gram each sample was macerated by scalpel and digested with $10 \mathrm{ml}$ of digestion mixture $(60 \mathrm{ml}$ of Nitric acid $(65 \%)$ and $40 \mathrm{ml}$ of perchloric acid $(70 \%)$ in screw capped tube for determination of lead, cadmium, and iron residues. Concerning mercury, $0.5 \mathrm{~g}$ of macerated sample was digested in $10 \mathrm{ml}$ of concentrated $\mathrm{H} 2 \mathrm{SO} 4 / \mathrm{HNO} 3$ solution (1:1). The tubes were closed and the entire were hardly shaken and then allowed to stand overnight. Then, heated for four hours in water bath beginning from $60 \mathrm{oC}$ up till $1100 \mathrm{C}$ for complete digestion

During the heating time, the digestive tract was vigorously shaken at 30 minutes. The tubes were then cooled and diluted by $1 \mathrm{ml}$ of de-ionized water (30\%) and heated by 70 $\mathrm{oC}$ in the water bath to ensure full digestion of the samples . Each tube has been dissolved with de-ionized water up to $25 \mathrm{ml}$ and filtered with filter paper No. 42 of Whattman. The filtrate was collected in polyethylene film-capped Pyrex glass test tubes and stored at room temperature until the mercury, lead, cadmium, and Iron concentrations were analyzed.

\subsubsection{Preparation of standard and blank solutions (Andreji} et al., 2005)

Instrumental procedures for various analysis were based on those suggested in the operator manual of the Flame Atomic Absorption Spectrophotometer (VARIAN, model AA240 FS, Australia). However, standard, and blank solutions were prepared similarly like wet digestion by the same chemicals .

Blank solution prepared by 10 parts of nitric acid with 1 part of $\mathrm{H} 2 \mathrm{O} 2$ then was diluted with 25 parts of deionized water and filtered. The blank was used to detect the contamination of metal which probably present in the chemicals and its value was discounted from the end calculated results.

\subsubsection{Analysis}

Flame Atomic Absorption Spectrophotometer (VARIAN, Australia, model AA240 FS) aspirate the digest, standard and blanks solutions analyze for cadmium, mercury, lead and iron concentrations. The apparatus has an auto sampler, digital absorbance, and concentration readout capable of operating under the following conditions recommended by the instrument instruction:

\begin{tabular}{llllll}
\hline Heavy metal condition & Mercury & Lead & Cadmium & Arsenic & Copper \\
\hline Lamp wavelength $(\mathrm{nm})$ & 253.7 & 283.3 & 228.8 & 193.7 & 324.8 \\
Lamp current $(\mathrm{m} / \mathrm{amp})$ & 10 & 10 & 4 & 7 & 15 \\
Fuel flow rate & 1.2 & 1.4 & 1.2 & 1.0 & 1.0 \\
Used gas & $\mathrm{A}-\mathrm{AC} *$ & Argon & Argon & AC/N2O & Argon \\
Measurement time & 4.0 & 4.0 & 4.0 & 4.0 & 4.0 \\
(seconds) & $1-5$ & $8-40$ & $2-8$ & $5-10$ & $8-40$ \\
Detection limit (ppb) & A- & AC/N2O= Acetylene/Nitic oxide &
\end{tabular}

2.1.5. Quantitative determination of heavy metal residues The absorption of mercury was recorded directly from the AAS digital scale and the concentration was determined as follows:

$\mathrm{C} 1=(\mathrm{A} 1 / \mathrm{A} 2) \times \mathrm{C} \times(\mathrm{D} / \mathrm{W}) \mathrm{mg} / \mathrm{kg}$

As,

$\mathrm{C} 1=$ mercury concentration $(\mathrm{mg} / \mathrm{kg})$ wet weight .

$\mathrm{A} 1=$ sample solution absorbency reading.

$\mathrm{A} 2=$ standard solution absorbency reading.

$\mathrm{C}=$ mercury Concentration on the standard solution.

$\mathrm{D}=$ Dilution factor for sample.

$\mathrm{W}=$ sample weight

While lead, cadmium, arsenic and copper concentrations were estimated according to the equation

$\mathrm{C}=\mathrm{R} \times(\mathrm{D} / \mathrm{W})$

As,

$\mathrm{C}=$ lead concentration $(\mathrm{mg} / \mathrm{kg})$ wet weight

$\mathrm{R}=$ digital scale of AAS reading.

$\mathrm{D}=$ sample dilution.

$\mathrm{W}=$ sample weight.

\subsection{Experimental part}

The effect of Lactobacillus rhamnosus as a biological trial for reduction the concentrations of lead experimentally inoculated into sardine fillets was studied as follow:

\subsubsection{Preparation of bacterial suspension}

In Brain Heart Infusion (BWI) Broth (Fluka, Sigma Aldrich Chemie $\mathrm{GmbH}$ ) were cultivated individually for 24 hours at $37 \mathrm{oC}$ to establish an overage culture in the strains Lactobacillus rhamnosus. One $\mathrm{ml}(1 \%)$, diluted in sterile peptone water in the bacterial suspension was cultivated $(0.1 \%, w / v)$ (Merck, Darmstadt, Germany). Accordingly, the viable count of Lactobacillus rhamnosus strains was carried out according to the plate count method (A volume of the culture broth corresponding to approximately $1 \times 107$ Lactobacillus rhamnosus was centrifuged $(500 \mathrm{rpm}, 15$ minutes at $5^{\circ} \mathrm{C}$ ) and the bacterial pellets were washed twice with deionized water (Halttunen et al.,2007).

\subsubsection{Binding assay}

The bacterial pellets were suspended in $1 \mathrm{Kg}$ sardine fillets. The mixture was adjusted to reach a final concentration of $5 \times 106$ bacteria according to Halttunen et al., (2008). Lead standard solutions were vortexed for 5 seconds (Stuart, Staffordshire, U.K.) and incubated for 24 hours on a Fine mixer SH2000 orbital shaker (Finepcr, Seoul, Korea) with soft agitation. Lead (without cultural bacteria) infected sardine fillets were used as a control test. The control group however described the contamination of fish fillets with lead and treatments with Lactobacillus rhamnosus. The samples were acidenced to ultrapure $\mathrm{HNO} 3$ and tested for lead levels as previously stated at $0,8,16$, and 24 hour times. 


\section{RESULTS}

The average values of mercury in the samples of Fesiekh, sardine, smoked herring and canned tuna were $1.14 \pm 0.02$, $0.98 \pm 0.01,0.83 \pm 0.01$ and $0.65 \pm 0.01 \mathrm{mg} / \mathrm{kg}$ respectively and in lead they were $0.54 \pm 0.01,0.42 \pm 0.01,0.29 \pm 0.01$ and $0.23 \pm 0.01 \mathrm{mg} / \mathrm{kg}$, respectively. The cadmium residues average concentrations in the samples of fesiekh, sardine, smoked herring and canned tuna were $0.33 \pm 0.01,0.21 \pm$ $0.01,0.16 \pm 0.01$ and $0.09 \pm 0.01 \mathrm{mg} / \mathrm{kg}$, respectively while, in iron they were $1.71 \pm 0.02,0.65 \pm 0.01,1.06 \pm$ 0.02 and $0.93 \pm 0.01 \mathrm{mg} / \mathrm{kg}$, respectively.

The effect of $L$. rhamnosus culture (1x107) on the levels of lead experimentally inoculated to sardine fillets $(30 \mathrm{mg} / \mathrm{Kg})$ was decreased to $13.8 \mathrm{mg} / \mathrm{kg}$ after 8 hours, $7.9 \mathrm{mg} / \mathrm{kg}$ after 12 hours and $6.5 \mathrm{mg} / \mathrm{kg}$ after 24 hours by a percentage of reduction $54 \%, 73.7 \%$ and $78.3 \%$ respectively.

\section{DISCUSSION}

Heavy metals are considered dangerous to human and living organisms by gradual accumulation in their bodies that present dangerous health hazards. (Wheaton and Lawson, 1985) .

The results recorded in Table (1) and figure (1) explained that the concentration of mercury in the samples of Fesiekh were between 0.27 to $1.88 \mathrm{mg} / \mathrm{kg}$, the average was $1.14 \pm$ $0.02 \mathrm{mg} / \mathrm{kg}$.

Table (1): Incidence and levels of mercury residues in the samples of fish products $(\mathrm{mg} / \mathrm{Kg})(\mathrm{n}=25)$.

\begin{tabular}{llllll}
\hline \multirow{2}{*}{ Fish products } & \multicolumn{1}{l}{ +ve samples } & \multirow{2}{*}{ Min } & Max & Mean \pm S.E \\
\cline { 2 - 3 } & No & $\%$ & & & \\
\hline Fesiekh & 19 & 76 & 0.27 & 1.88 & $1.14 \pm 0.02$ \\
Sardine & 18 & 72 & 0.21 & 1.53 & $0.98 \pm 0.01$ \\
Smoked herring & 15 & 60 & 0.14 & 1.39 & $0.83 \pm 0.01$ \\
Canned tuna & 13 & 52 & 0.11 & 1.25 & $0.65 \pm 0.01$ \\
\hline
\end{tabular}

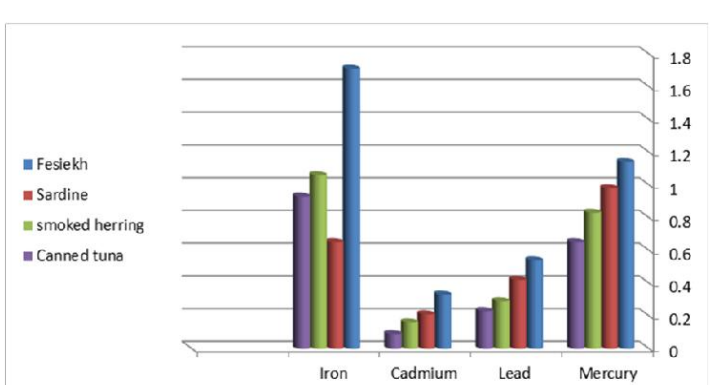

Figure (1): The mean average of concentrations of mercury, lead, cadmium, and iron residues in the examined fish products $(\mathrm{mg} / \mathrm{Kg})$.

Mercury concentration in sardine lied between 0.21 to 1.53 $\mathrm{mg} / \mathrm{kg}$, the average was $0.98 \pm 0.01 \mathrm{mg} / \mathrm{kg}$. Also, mercury concentration in the examined samples of smoked Herring were from 0.14 to $1.39 \mathrm{mg} / \mathrm{kg}$, the average was of $0.83 \pm$ $0.01 \mathrm{mg} / \mathrm{kg}$.

The concentration of mercury in the examined samples of canned tuna ranged between 0.11 to $1.25 \mathrm{mg} / \mathrm{kg}$, the average was $0.65 \pm 0.01 \mathrm{mg} / \mathrm{kg}$. These results agree with those recorded by Sallam (1997) and Lamada-Hanan (2003). Lower results were recorded by Shoe et al., (1991). On the other hand, higher results were reported by Abd ElKader et al. (1993) and Aceto et al .(1995),.

According to EOS (2010) which stated that the maximal limits permitted for mercury is $0.5 \mathrm{mg} / \mathrm{kg}$ in fish, the number of un-accepted samples are $11,9,8$ and 6 represented as $44 \%, 36 \%, 32 \%$ and $24 \%$ in the examined Fesiekh, Sardine, Smoked herring and Canned tuna, respectively (Table2).
Table (2): Acceptability of the fish products according to their mercury residues $(\mathrm{n}=25)$.

\begin{tabular}{llllll}
\hline \multirow{2}{*}{ Fish products } & \multirow{2}{*}{ MRL $(\mathrm{mg} / \mathrm{Kg}) *$} & \multicolumn{2}{c}{ Accepted samples } & \multicolumn{2}{c}{ Unaccepted samples } \\
\cline { 3 - 6 } & & No. & $\%$ & No. & $\%$ \\
\hline Fesiekh & 0.5 & 14 & 56 & 11 & 44 \\
Sardine & 0.5 & 16 & 64 & 9 & 36 \\
Smoked herring & 0.5 & 17 & 68 & 8 & 32 \\
Canned tuna & 0.5 & 19 & 76 & 6 & 24 \\
Total (100) & & 66 & 66 & 34 & 34 \\
\hline * EOS (2010) & & \multicolumn{3}{c}{}
\end{tabular}

Mercury is accurately regarded as a highly toxic metal and is strictly regulated for waste disposal (Grress and Lord, 2002) .

Lead concentrations in Fesiekh samples were between 0.17 to $1.02 \mathrm{mg} / \mathrm{kg}$, the average was $0.54 \pm 0.01 \mathrm{mg} / \mathrm{kg}$ as in table (3) and figure (1).

Table (3): Incidence and levels of lead residues in the samples of fish products $(\mathrm{mg} / \mathrm{Kg})(\mathrm{n}=25)$.

\begin{tabular}{llllll}
\hline \multirow{2}{*}{ Fish products } & \multicolumn{2}{l}{+ +ve samples } & \multirow{2}{*}{ Min } & Max & Mean \pm S.E \\
\cline { 2 - 3 } & No & $\%$ & & & \\
\hline Fesiekh & 16 & 64 & 0.17 & 1.02 & $0.54 \pm 0.01$ \\
Sardine & 14 & 56 & 0.10 & 0.91 & $0.42 \pm 0.01$ \\
Smoked herring & 11 & 44 & 0.08 & 0.64 & $0.29 \pm 0.01$ \\
Canned tuna & 10 & 40 & 0.03 & 0.59 & $0.23 \pm 0.01$ \\
\hline
\end{tabular}

In the examined samples of Sardine lead concentration ranged from 0.10 to $0.91 \mathrm{mg} / \mathrm{kg}$, the average was $0.42 \pm$ $0.01 \mathrm{mg} / \mathrm{kg}$ lower results were obtained by El - Sayed (2010) and Martinez et al.(1983) .

Lead concentration in the examined samples of smoked Herring ranged from 0.08 to $0.64 \mathrm{mg} / \mathrm{kg}$, the average was $0.29 \pm 0.01 \mathrm{mg} / \mathrm{kg}$ higher results were obtained by $\mathrm{El}$ Sayed (2010) and Şireli et al.(2006) .

The mercury concentrations of in the examined samples of canned tuna ranged between 0.03 to $0.59 \mathrm{mg} / \mathrm{kg}$, the average was $0.23 \pm 0.01 \mathrm{mg} / \mathrm{kg}$ lower results were obtained by El - Sayed (2010), Shoe et al. (1991), Tahan et al. (1995) and Tariq et al.(1994) .

Table (4): Acceptability of the examined fish product samples according to their lead residues $(n=25)$.

\begin{tabular}{llllll}
\hline \multirow{2}{*}{ Fish products } & \multirow{2}{*}{ MRL $(\mathrm{mg} / \mathrm{Kg}) *$} & \multicolumn{3}{c}{ Accepted samples } & \multicolumn{3}{c}{ Unaccepted samples } \\
\cline { 3 - 6 } & & No. & $\%$ & No. & $\%$ \\
\hline Fesiekh & 0.3 & 15 & 60 & 10 & 40 \\
Sardine & 0.3 & 17 & 68 & 8 & 32 \\
Smoked herring & 0.3 & 18 & 72 & 7 & 28 \\
Canned tuna & 0.3 & 20 & 80 & 5 & 20 \\
Total (100) & & 70 & 70 & 30 & 30 \\
\hline * EOS $(2010)$ & & & & &
\end{tabular}

$*$ EOS (2010)

According to EOS (2010) which mentioned that the maximal limits permitted for lead is $0.10 \mathrm{mg} / \mathrm{kg}$ in fish, the number of un-accepted samples are 10, 8, 7and 5 represented as $40 \%, 32 \%, 28 \%$ and $20 \%$ in the examined Fesiekh, Sardine, Smoked herring and Canned tuna, respectively.

Table (5) and figure (1) discussed cadmium concentrations in the examined samples of fesiekh ranged between 0.04 to 0.65 , the average was $0.33 \pm 0.01$, while salted sardine were from 0.02 to 0.37 , the average was 0.21 \pm 0.01 and smoked herring ranged from 0.02 to 0.31 , the average was $0.16 \pm 0.01$ and Canned tuna ranged from 0.01 to 0.18 , the average was $0.09 \pm 0.01 \mathrm{mg} . \%$

Table (5): Incidence and levels of Cadmium residues in fish products samples $(\mathrm{mg} / \mathrm{Kg})(\mathrm{n}=25)$

\begin{tabular}{|c|c|c|c|c|c|}
\hline \multirow[b]{2}{*}{ Fish products } & \multicolumn{2}{|c|}{+ ve samples } & \multirow[b]{2}{*}{ Min } & \multirow[b]{2}{*}{$\operatorname{Max}$} & \multirow[b]{2}{*}{ Mean \pm S.E } \\
\hline & No & $\%$ & & & \\
\hline Fesiekh & 15 & 60 & 0.04 & 0.65 & $0.33 \pm 0.01$ \\
\hline Sardine & 12 & 48 & 0.02 & 0.37 & $0.21 \pm 0.01$ \\
\hline Smoked herring & 10 & 40 & 0.02 & 0.31 & $0.16 \pm 0.01$ \\
\hline Canned tuna & 7 & 28 & 0.01 & 0.18 & $0.09 \pm 0.01$ \\
\hline
\end{tabular}

According to EOS (2010) which recommended that the maximal permissible limit for cadmium is $0.10(\mathrm{mg} / \mathrm{kg})$, 
the number of un-accepted samples are 13, 9, 7and 4 represented as $52 \%, 36 \%, 28 \%$ and $16 \%$ in the examined Fesiekh, Sardine, Smoked herring and Canned tuna, respectively.

Table (6): Acceptability of the examined fish products according to their cadmium residues $(\mathrm{n}=25)$.

\begin{tabular}{llllll}
\multirow{2}{*}{ Fish products } & MRL $(\mathrm{mg} / \mathrm{Kg})^{*}$ & \multicolumn{2}{c}{ Accepted samples } & \multicolumn{2}{c}{ Unaccepted samples } \\
\cline { 3 - 6 } & & No. & $\%$ & No. & $\%$ \\
\hline Fesiekh & 0.05 & 12 & 48 & 13 & 52 \\
Sardine & 0.05 & 16 & 64 & 9 & 36 \\
Smoked herring & 0.05 & 18 & 72 & 7 & 28 \\
Canned tuna & 0.05 & 21 & 84 & 4 & 16 \\
Total (100) & & 67 & 67 & 33 & 33 \\
\hline
\end{tabular}

* EOS (2010)

Cadmium as extremely toxic metal is considered as one of the most dangerous pollutants (Cowley, 1978). In human, $\mathrm{Cd}$ is highly cumulative poison with a biological half-life about 20-30 years in human body (Manahan, 1992).

Table (7) and figure (1) showed that the concentrations of iron in the examined samples of fesiekh ranged from 0.86 to 2.90 , the average was $1.71 \pm 0.02$, while in salted sardine they ranged from 0.34 to 1.12 , the average was $0.65 \pm$ 0.01 and in smoked herring they ranged from 0.61 to 1.78 , the average was $1.06 \pm 0.02$ and in canned tuna they ranged from 0.57 to 1.44 , the average was $0.93 \pm 0.01 \mathrm{mg} . \%$ Table (7): Incidence and levels of iron residues $(\mathrm{mg} / \mathrm{Kg})$ in the examined samples of fish products $(\mathrm{n}=25)$.

\begin{tabular}{llllllr}
\hline \multirow{2}{*}{ Fish products } & \multicolumn{3}{c}{+ +ve samples } & \multirow{2}{*}{ Min } & Max & \\
\cline { 2 - 3 } & No & $\%$ & & & \\
\hline Fesiekh & 15 & 60 & 0.86 & 2.90 & $1.71 \pm 0.02$ \\
Sardine & 12 & 48 & 0.34 & 1.12 & $0.65 \pm 0.01$ \\
Smoked herring & 10 & 40 & 0.61 & 1.78 & $1.06 \pm 0.02$ \\
Canned tuna & 7 & 28 & 0.57 & 1.44 & $0.93 \pm 0.01$ \\
\hline
\end{tabular}

The effect of $L$. rhamnosus culture (1x107) on the levels of lead experimentally inoculated to sardine fillets $(30 \mathrm{mg} / \mathrm{Kg})$ was decreased to $13.8 \mathrm{mg} / \mathrm{kg}$ after 8 hours, $7.9 \mathrm{mg} / \mathrm{kg}$ after 12 hours and $6.5 \mathrm{mg} / \mathrm{kg}$ after 24 hours by a percentage of reduction $54 \%, 73.7 \%$ and $78.3 \%$ respectively Table (8) and Figure.(2)

Table (8): Effect of L.rhamnosus culture $(1 \times 107)$ on the levels of lead experimentally inoculated to sardine fillets $(30 \mathrm{mg} / \mathrm{Kg})$.

\begin{tabular}{|c|c|c|c|}
\hline Group & Control $(\mathrm{mg} / \mathrm{Kg})$ & L.rhamnosus & \\
\hline Storage time & & Treated group $(\mathrm{mg} / \mathrm{Kg})$ & Reduction \% \\
\hline Zero time & 30 & 30 & ----- \\
\hline 8 hours & 30 & 13.8 & 54.0 \\
\hline 16 hours & 30 & 7.9 & 73.7 \\
\hline 24 hours & 30 & 6.5 & 78.3 \\
\hline
\end{tabular}

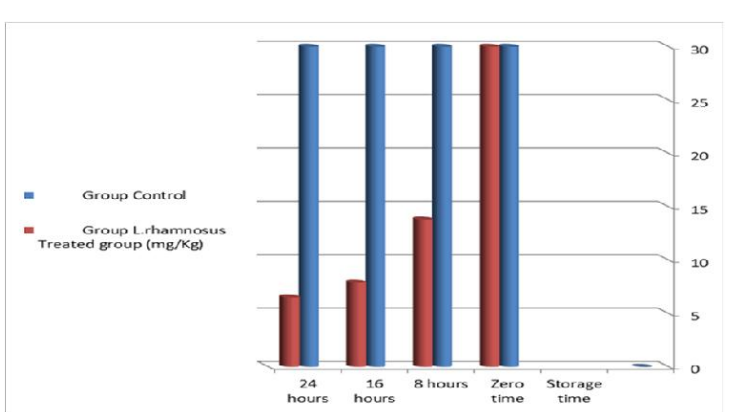

Figure (2): Lead residues $(\mathrm{mg} / \mathrm{Kg})$ in the control and L.rhamnosus treated sardine fillet samples.

The bio-adsorption method used in controlling and removing mineral pollution has received great attention because of its application efficiency. These biomass adsorbents have the ability to retain minerals and reduce the concentration of heavy metal ions in solution from ppm to ppt. The mechanisms responsible for bio- adsorption can be a mode of ionic exchange, complex formation, rearrangement, adsorption, static reactions, and Chelating compounds and micro-deposition (Al-Masri and Amin, 2010).

\section{Conclusion}

The obtained results allow to conclude that most of fish products exposed for consumption were contaminated with different chemical residues such as heavy metals (lead, mercury, Cadmium, and iron)

Feisiekh contained the highest level of Mercury, Lead, Cadmium, and Iron, while canned tuna contained the lowest level of the first three heavy metals and Sardine contained the lowest level of the last one.

Application of L.rhamnosus culture as a starter culture in salted fish products fermentation is effective to inhibit heavy metals accumulation and to enhance the safety of salted and fermented fish products.

\section{REFERENCES}

1. Abd-El-Kader, M.A.; Tork, I.; Amine, M.A. and Aref, M.A. (1993). Heavy metal pollution in fishponds. Zag. Vet. J., 21:116.

2. Aceto, M.; Foglizzo, A.M.; Mentasti, E.; Sacchero, G. and Sarzanim, C. (1995). Mercury specification in biological samples. International J. of Environ .Anal. Chem., 60:1 .

3. Al-Masri, M. S. and Amin, Y. (2010). The Use of biosorbents for heavy metals removal from aqueous media. Syrian Arab Rebablic, Atomic Energy Commission, Damaskus. Department of Protection and Safety, AECS - PR $\backslash$ RSS 872 . https://inis.iaea.org/collection/NCLCollectionStore/_Public/41 /099/41099960.pdf

4. Andreji, J.; Stranai, Z.; Massonyl, P. and Valent, M. (2005).Concentration of selected metal in muscle of various fish species. J. Environ. Sci. Heal. 40 (4):899-912 .

5. Bakhiet, H. H. A. (2015). Determination of heavy metals in fish tissues and water from White Nile Khartoum City-Sudan. J. Environ. Protect. Sustainable Dev., 1(3): 178-181 .

6. Cowley, K. M. (1978). Atomic Absorption Spectroscopy in Food Analysis, In: King R.D. (ed). In: King R.D. (1978): Developments in Food Analysis Techniques- 1- Applied Science Publishers Ltd. Ripple Road. Barking, Essex England.

7. Daoud-Jehan, R.; Aida, M.A. and Abd El- Khalek, M.M (1999). Residual analysis of some heavy metals in water and Oreochromis niloticus fish from polluted areas. Vet. Med. J. Giza 47:351-365.

8. Egyptian Organization for Standardization "EOS" (2010). Maximum Levels for certain contaminants in foodstuffs. No 7136/2010. Egyptian Standards, Ministry of Industry, Egypt.

9. El-Sayed, E.A. (2010). Studies on some chemical residue in fish and its products ph. D. thesis, Fac.Vet. Med.,Benha university

10. Environmental Working Group (2010). Lead compounds. Retrieved November5,2010,from http://www.ewg.org/ chem index/ term/ 455.

11. Franciosa, I.; Alessandria, V.; Dolci, P.; Rantsiou, K. Cocolin, L. (2018): Sausage fermentation and starter cultures in the era of molecular biology methods. Int. J. Food Microbiol. 2018, 279, 26-32.

12. Grress, L. and Lord, J. (2002). Return and recycling of used high intensity bulbs for recycling and closed-loop mercury control. In mercury in products, Processes, Waste and the Environment: Eliminating, reducing and Managing risks from Non- Combustion Sources (ed.Oppelt, E.T.0, proceedings and Summary Reports EPA .

13. Halttunen T., Collado, M., El-Nezami, H., Meriluoto, J., Salminen, S. (2008): Combining strains of lactic acid bacteria 
and heavy metal removal efficiency from aqueous solution. Letters Appl. Microbiol. 46:160-165 .

14. Halttunen, T., Salminen, S., Tahvonen, R. (2007): Rapid removal of lead and cadmium from water by specific lactic acid bacteria. Inter. J. Food Microbiol.114: 30-35.

15. Lamada-Hanan, M.O. (2003). Studies on some toxic residues in fish and shell fish. Ph. D. Thesis, Vet. Med. Sc. Dept. F Control. ,Fac. Vet. Med. Zagazig University (Benha branch ) .

16. Laranjo, M.; Elias, M. and Fraqueza, M.J. (2017). The use of starter cultures in traditional meat products. J. Food Qual. 2017, 9546026.

17. Lehmann, I.; Sack, U. and Lehmann, J. (2011). Metal ions affecting the immune system. Metal ions in life sciences journal, 8, 157-185.

18. Manahan S.E. (1992). Toxicological chemistry, 2nd Ed. Lewis publishers Inc . Boca Raon, Ann. Arbor, London, Tokyo .

19. Martinez-para, M.C.; Masoud, T.A. and Polo, M.I. (1983). Minerals in fish canned with oils. Estimation of lead, cadmium and tin. Dep. Bromatologion. Madrid, Spain. 34 (2): 169-176.

20. Nkpaa, K.W.; Wegwu, M.O. and Essien, E.B. (2013). Heavy metals concentrations in four selected seafood from crude oil polluted waters of Ogoniland, Rivers State, Nigeria. Archives of Applied Science Research, 5(4), 97-104.

21. Oehlenschläger, J. (2005). Identifying heavy metals in fish. In: Safety and Quality Issues in Fish Processing. Ed: Bremner, H.A. WoodheadPublishing Limited and CRC Press LLC. pp. 95-108.

22. Sallam, Kh. I. (1997). Heavy metal residues in fishes and their relation to public health. Ph. D. Thesis, Fac. Vet. Med., Zagazig Univ., Egypt .

23. Scoullos, M.; Vonkeman, D.; Thorxton, I. and Makuch, Z. (2001).Cadmium, mercury, lead. Handbook for sustainable heavy metals policy and regulation. Edited by M. scouttos (Dordrecht; Kluwer), 2710 .
24. Shoe, H.J.; Hong, S.S and Krin, G.M. (1991). A study on the contents of heavy metals in fresh water fish of Yong San River J. Kor. Soc. Food Nutr., 20: 615 .

25. Şireli, U. T.; Göncüoğlu , M.; Yıldırım, Y.; Göncüoğlu, A. and Çakmak, O. (2006). Assessment of Heavy Metals (Cadmium and Lead) in Vacuum Packaged Smoked Fish Species.E.U.Journal of Fisheries and Aquatic Sciences.Cilt/ 23, (3-4): 353-356.

26. Staniskiene, B.; Matusevicius, P.; Budreckiene, P. and Skibniewska, K.A. (2006). Distribution of heavy metals in tissues of freshwater fish in Lithuania. Polish J. Environ Studies, 15(4): 585-591.

27. Storelli, M.M. and Marcotrigiano, G.O. (2001). Consumption of bivalve molluscs in Italy:estimated intake of cadmium and lead. Food Addit. andContam., 18 (4): 303.

28. Tahan, J.E.; Sanchez, J.M.; Cranadillo, V.A.; Cubillan, H.S. and Romero, R.A. (1995). Concentration of total $\mathrm{Al}, \mathrm{Cr}, \mathrm{Cu}$, $\mathrm{Fe}, \mathrm{Hg}, \mathrm{Na}, \mathrm{Pb}$ and $\mathrm{Zn}$ in commercial canned seafood determined by atomic spectrometric means after mineralization by microwave heating. J.Agric. Food Chem., 34:910.

29. Tariq, J.; Jaffar, M. and Ashraf, M. (1994). Assessment of pollution of rivers Jehlum and Sutlej Pakistan through trace metals in fish, sediment and water. Toxicol. Environm. Chem., 43:169.

30. Wheaton, F. and Lawson, T. (1985). Processing of aquatic food product. A widely inter. Sci. Publ., New York, pp.231232.

31. World Health Organization "WHO" (2004). Toxicological evaluation of certain food additives and contaminants. Technical Report Series No 52 (Geneva: WHO).

32. Vilizzi, L. and Tarkan, A.S. (2018). Bioaccumulation of metals in common carp (Cyprinus carpio L.) from water bodies of Anatolia (Turkey): a review with implications for fisheries and human food consumption. Environ. Monit. Assess., 188:242. DOI 10.1007/s10661-016-5248-9 